\title{
TEACHERS' CITIZENSHIP BEHAVIOR AS A PREDICTOR OF TEACHING PERFORMANCE: EVIDENCE FROM PAKISTANI CONTEXT
}

Muhammad Shabbir Ali $^{1 *}$, Muhammad Siddique ${ }^{2}$, Ahsaan Siddique ${ }^{3}$, Muhammad Abbas $^{4}$, Saba Ali $^{5}$

${ }^{1 *}$ Associate Professor Education, University of Education Faisalabad Campus, Pakistan; ${ }^{2} \mathrm{Ph} . \mathrm{D} .$, Scholar Education, University of Education, Lahore, Pakistan; ${ }^{3} \mathrm{Ph}$.D., Scholar at Institute of Education and Research, University of the Punjab, Lahore, Pakistan; ${ }^{4,5} \mathrm{Ph} . \mathrm{D}$., Scholar Education, University of Education, Lahore, Pakistan. Email: ${ }^{1 *}$ shabbir.alisaleemi@ue.edu.pk, ${ }^{2}$ siddiqueamar@gmail.com, ${ }^{3}$ ahsaansiddique1@yahoo.com, 4mas1798@gmail.com, 5 saba.zulfiqar.ali@gmail.com Article History: Received on $17^{\text {th }}$ June 2021, Revised on $22^{\text {nd }}$ June 2021, Published on $23^{\text {rd }}$ June 2021

\section{Abstract}

Purpose of the study: The current study investigated the correlation between teachers' organizational citizenship behavior and teaching performance at the primary level in the Lahore division of Punjab province, Pakistan.

Methodology: Researchers structured the descriptive and quantitative research, directed the positivistic paradigm, and obeyed the correlational design. The sample was selected on a random sampling technique named multi-stage sampling. Two hundred ninety subjects comprising male and female were selected from primary school. Two closed-ended tools were applied to collect the data. Both research instruments were pilot tested to ensure validity and reliability. Inferential statistical analysis techniques such as Pearson $r$, regression analysis, independent t-test, and one-way ANOVA were run for data analysis.

Principal Findings: The results revealed a moderate statistically significant positive correlation between teachers' organizational citizenship behavior and teaching performance.

Applications of this study: The current study is helpful in how teaching performance can be enhanced at the primary level in the Lahore division of Punjab province, Pakistan.

Novelty/Originality of this study: for the first time, the association between organizational citizenship behavior and teaching performance at the primary level is examined in an emerging country like Pakistan.

Keywords: Teachers' Organizational Citizenship Behavior, Teaching Performance, Primary School Teachers, Pakistan and Correlation.

\section{INTRODUCTION}

According to Hemaloshinee and Nomahaza (2017), organizational citizenship behavior donates to decreasing the organization's need to provide resources, cohesion, and administrative unity and helping employees for exertion by allotting space to effectual scheduling as well as resolving the issues, dilemmas, and problems. Dinka (2018) and Pekaar (2016) explained that A person's voluntary willingness to the organization for OCB is not for contractual tasks. Helping others in workloads does not keep burden, and keep up betterment in the company. According to Klotz (2018), OCB is associated with the incentives and proficiencies of the individuals.

The teachers in a school can improve the output of the institute as well as the vision and mission of the institute. Teachers' professionalism is a must for this betterment as teachers produce an educator, cognitive, affective, and psychomotor aspects. A teacher performs Organizational Citizenship Behavior (OCB) to the school for positive change except for his job description. OCB is suitable for time management, willingness to become honest in a developing environment. Open attitude of teachers' changes, the effort of self-developing, restrain from conflict of coworkers, not complaining attitude, and constant as positive to cover problems (Khan, Khan, Ullah, Usman, Farhat, 20201 Makruf, Putra, Muharom, Hafidah, \& Maslamah, 2021; Shaikh, Channar, \& Shaikh, Ullah, (2021).

According to Podsakoff et al. (2009) and Silva \& Madhumali (2014), OCB is personage behavior that encourages the organization's functioning. OCB affects organizational effectiveness and success (Deery et al., 2017; Jafari \& Bidarian, 2012; Ullah, Shaikh, Channar, \& Shaikh, 2021).

Jex and Thomas told behavior expressively are the notion of OCB as defined by Organ is as (Jex, Steve M \& Britt, 2008): "helping behaviors is the core of any organization which is termed some-times as pro-social behavior. Employee's voluntarily assisting as a coworker is an example of this pattern. Conscientiousness is a constructive component, and it produces good citizens at the workplace. Civic virtue is also a component of OBS's ineffective workplace. A charitable function sponsored by the organization is an example of OCB also (Jex et al., 2008).

An effective school is assessed from the OCB. Helping others, being helpers, assisting the complete organization goals are OC behaviors (Newstorm \& Davis, 2002). Organizational citizenship behavior is designed to help others better their efforts for projects, share time and resources, and cooperate with others. Teachers are the fundamental component for such changes. OCB is obligatory for teaching. According to Somech and Ron (2007), ethical and moral values, aim, goals and objective, and teacher and educational institutions are interlinked with one another (Somech \& Oplatka, 2014), 
and institutions "cannot anticipate through formally stated in-role job descriptions the entire array of behaviors needed for achieving (their) goals" (Belogolovsky \& Somech, 2010, p. 914).

School effectiveness can be improved through existing work by indicators, including work willingness on a complex basis (Schermerhorn, John. Hunt, James. Osborn, Richard, \& Bien, 2010) that able teachers achieve OCB during work". OCB tells teacher's competency (Darsana, 2013; Ullah, Malik, Zeb, Rehman, 2019). OCB is of various forms "They include different behaviors such as volunteering for assignments, going out of one's way to welcome new employees, helping others who need assistance, staying late to finish a task, or voicing one's opinion on critical organizational issues" (Wagner III \& Hollenbeck, 2010).

\section{LITERATURE REVIEW}

Teachers have a significant impact on the learners' betterment to recognize goals of life. Parents have global-based environment expectations from teachers for their children for good citizen development. Teachers' professionalism as educators is necessary for human improvement. Teachers as educators need to improve their learning quality and learners' competence (Askafi, Chandrarin, Assih, \& Respati, 2017).

The citizenship behavior works under different effects that confirm that behavior plays a role for the persons and institutions. An Individual's personal life reflects these behaviors, which may reduce the performance of the individuals that can negatively impact organizational performance (Shanker, 2018). Successful organizations care about employees' issues to enhance continuous performance (Shahin et al., 2014). Focus on organization citizenship behaviors scope is also important factors that affect employees and organization (ALHussain, 2011). Alkahtani (2015) reported incentives are essential for motivational forces in an organization's employees; Employee motivation aimed to establish employees' encouragement in work. These systems should be based on scientific outcomes to achieve employees' satisfaction and improve organizational performance (Mamdani \& Minhaj, 2016).

A broad range of activities of Teachers' OCBs prolonged to institute colleagues, supervisors, and student's participation in an educational institution at a considerable level (Somech \& Drach-Zahavy, 2000). Ghanizadeh and Jahedizadeh (2015) explored that OCB's day-by-day experiences are not investigated to epoch. Teachers' well-being is essential alarms in existing education research, and teachers' regarding sign indicating popularity regarding its suffer exhaustion ( Hakanen et al., 2006; Schaufeli \& Buunk, 2003) and Shen et al. (2015) and Grant (2017) disturbing impacts upon teachers' weakened performance. So, investigative prospective destructive impacts of such teachers' OCB upon wellbeing and discovering associated dynamics are of concern not for educational researchers, educators, and policymakers.

Organizational citizenship is discriminating behavior which means doing tricks than obeying an institution's rules. Incentives will increase organizational citizenship behavior among employees (Mokhniuk, 2016; Khan, Ullah, 2021). OCB concerning performance increase the output of an organization (Khazaei et al., 2011). Performing OCB voluntarily outside responsibilities significantly impacts organization output, which improves performance (Sadeghi et al., 2018).

According to Iqbal et al. (2012), researchers have a profound influence on the success and better performance of the organizations through employee behavior for OCB's importance. OCB performance means to achieve one's effort under his managing ability in complex situations (Troena \& Noermijati, 2013). Conscientiousness, altruism, citizenship, virtue, generosity, respect are components of OCB that are significant to performance (Khazaei et al., 2011; Troena \& Noermijati, 2013; Sadeghi et al., 2018).

Fitriastuti (2013) tells in his research about the effect of organizational citizenship behavior on civil servant performance that explored employees are influenced by OCB. It affects the achievement of organizational goals achievement because OCB improves employee performance. Khazaei, Khalkhali, and Eslami (2011) said that the variable of OCB holds an effect on employees' performance. According to other research studies, a positive impact affects OCB performance (Abrar \& Isyanto, 2019; Lestari \& Ghaby, 2018; Sari, 2015).

Yuwanda and Pratiwi (2020) explored the study to see the impact of organizational citizenship behavior on job performance. They found that OCB had positive effects on workers' job performance. Yaakobi and Weisberg (2020) suggested that organizational citizenship behavior contributes to enhancing corporate innovation and improving its quality. It assists in the development of workers' job satisfaction and their job performance. It enhances their collaboration in the organization. OCB might be fruitful for teachers to perform effectively within the classroom scenario (De Geus, Ingrams, Tummers, \& Pandey, 2020). OCB plays a creative role in improving educational quality in any educational institution. Teachers' OCB may play a constructive role in fostering their teaching performance. OCB helps teachers overcome hurdles in the classroom scenario effectively (Hazzi, 2018). Organ (2018) conducted a study and found that teachers' OCB was the primary indicator of teaching effectiveness. The educational ends might be achieved easily when teachers had OCB (Somech \& Oplatka, 2015).

\section{Research Objectives}

Following were the primary objectives of the current research:

1. To investigate the correlation between teachers' OCB and TP. 
2. Compare the difference in teachers' OCB and TP regarding their gender, job type, academic qualifications, and teaching experience.

3. To examine the effect of teachers' OCB on TP.

\section{RESEARCH DESIGN AND METHODOLOGY}

\section{Research Design}

The researcher adopted a positivist paradigm to conduct the study. The study was descriptive-correlational and quantitative.

\section{Population and Sampling Procedure}

The population consisted of all the primary school teachers of the Lahore division. Multi-stage random sampling was adopted to select the sample. Lahore Division was comprised of 4 districts. At the $1^{\text {st }}$ stage, one section was chosen out of 4 districts of the Lahore division by using a random sampling technique. At the second stage, forty boys and 40 girls' primary schools were selected randomly from one selected district of the Lahore division. At the $3^{\text {rd }}$ stage, the census strategy was adopted for selecting the subjects in the current study. The total sample was 290 subjects working in the Lahore division at the primary level.

\section{Research Instruments}

Two closed-ended tools were used to collect the data from selected individuals. Siddique (2016) used OCB questionnaires in his M.Phill thesis at the Punjab, Lahore, Pakistan. Firstly, Konovsky and Organ (1996) developed a 5points Likert scale to assess teachers' OCB at the primary school level. It constitutes five factors: altruism, courtesy, sportsmanship, conscientiousness, and civic virtue. Secondly, Amin, Shah, Ayaz, and Atta (2013) developed a 5-points Likert scale to assess teachers' job performance was used. It is a self-report measure with six sub-scales: "student-teacher relationship, facilitative classroom environment, content, pedagogical knowledge, classroom management, punctuality and regularity, and teaching assessment skills" (pp. 102-103). The reliability value of this instrument was 0.90. Data collection was done through contacts by mail and during personal visits to the schools. Pearson $r$ was applied to explore the relationship between OCB and TP. Regression Analysis was done to examine the effect of teachers' OCB on TP. Independent t-test and one-way ANOVA were applied to see the difference concerning teachers' job type, academic qualifications, and experience in years.

\section{Data Analysis and Interpretations}

Table 1: Relationship of Organizational Citizenship Behavior (OCB) and Teaching Performance (TP)

\begin{tabular}{llll}
\hline Variables & $\boldsymbol{n}$ & $\boldsymbol{r}$-value & Sig. \\
\hline Organizational Citizenship Behavior and Teaching Performance & 290 & $.623^{* *}$ & .001 \\
\hline
\end{tabular}

$p<.001$ (2-tailed)

Table 1 revealed the relation between OCB and TP by using Pearson $r$. It is concluded that OCB had positive significant relationship with their TP, $r=.623, n=290, p<.001$.

Table 2: Correlation of OCB factors with TP

\begin{tabular}{lllllll}
\hline Factors of OCB and TP & $\mathbf{1}$ & $\mathbf{2}$ & $\mathbf{3}$ & $\mathbf{4}$ & $\mathbf{5}$ & $\mathbf{6}$ \\
\hline Altruism & 1 & $.651^{* *}$ & $.271^{* *}$ & $.305^{* *}$ & $.307^{* *}$ & $.47^{* *}$ \\
\hline Courtesy & & 1 & $.157^{* *}$ & $.184^{* *}$ & $.359^{* *}$ & $.278^{* *}$ \\
\hline Sportsmanship & & 1 & $.337^{* *}$ & -.049 & $.591^{* *}$ \\
\hline Conscientiousness & & & 1 & $.369^{* *}$ & $.544^{* *}$ \\
\hline Civil virtue & & & & & 1 & $.139^{*}$ \\
\hline Teaching Performance & & & & & 1 \\
\hline
\end{tabular}

$n=290, * * p<.001$ (2-tailed)

Table 2 revealed that the relation between OCB sub-variables with TP. The sub-scales of OCB such as Altruism $(r=$ $.427 * *)$, Courtesy $\left(r=.278^{* *}\right)$, Sportsmanship $\left(r=.591^{* *}\right)$, Conscientiousness $(r=.544 * *)$, and Civic virtue $(r=$ $\left..139^{* *}\right)$ had positive correlation with TP. It is concluded that the OCB factors were having positive significant correlation with TP.

Table 3: Independent t-test by male and female concerning the subscales of OCB and TP

\begin{tabular}{llllllll}
\hline Sub-scales of OCB \& TP & Gender & $\boldsymbol{N}$ & Mean & $\boldsymbol{S D}$ & $\boldsymbol{t}$ & $\boldsymbol{d} \boldsymbol{f}$ & $\boldsymbol{P}$ \\
\hline $\mathrm{OCB}$ & Male & 181 & 40.3425 & 7.80839 & -1.837 & 288 & .131 \\
\hline & Female & 109 & 42.2202 & 9.38118 & & & \\
\hline TP & Male & 181 & 72.6630 & 13.62605 & -1.797 & 185.259 & .001 \\
\hline
\end{tabular}


An independent t-test was run to see the difference in OCB and TP in teachers' gender. Table 3 indicated that only one variable such as TP: male $(\mathrm{M}=72.6630, \mathrm{SD}=13.62605)$ and female, $\mathrm{M}=76.2018, \mathrm{SD}=17.63403 ; \mathrm{t}(-1.797)=185.259$, $\mathrm{p}=.001$, had significant difference with respect to their gender. Results show that teachers' OCB had no significant difference in terms of gender.

Table 4: Independent t-test by job type concerning the subscales of OCB and TP

\begin{tabular}{llllllll}
\hline Sub-scales of OCB \& TP & Job Type & $\boldsymbol{N}$ & Mean & $\boldsymbol{S D}$ & $\boldsymbol{t}$ & $\boldsymbol{d} \boldsymbol{f}$ & $\boldsymbol{P}$ \\
\hline OCB & Permanent & 225 & 41.6089 & 8.48307 & 2.110 & 288 & .593 \\
\hline & Contract & 65 & 39.1077 & 8.18177 & & & \\
\hline TP & Permanent & 225 & 75.7778 & 14.13943 & 3.345 & 89.137 & .001 \\
\hline & Contract & 65 & 67.8154 & 17.62269 & & & \\
\hline
\end{tabular}

An independent t-test was run to see the difference in OCB and TP in teachers' gender. Table 4 indicated that only one variable such as $\mathrm{TP}$ : permanent $(\mathrm{M}=75.7778, \mathrm{SD}=14.13943)$ and contract teachers, $\mathrm{M}=67.8154, \mathrm{SD}=17.62269 ; \mathrm{t}$ $(3.345)=89.137, \mathrm{p}=.001$, had significant difference with respect to their job type. Results show that teachers' OCB had no significant difference in terms of teachers' job type.

Table 5: One way ANOVA on OCB and TP regarding Academic qualification

\begin{tabular}{lllllll}
\hline & & Sum of Squares & $d f$ & Mean Square & $\boldsymbol{F}$ & Sig. \\
\hline \multirow{2}{*}{ OCB } & Between Groups & 82.310 & 2 & 41.155 & .572 & .565 \\
\cline { 2 - 8 } & Within Groups & 20637.015 & 287 & 71.906 & & \\
\cline { 2 - 7 } & Total & 20719.324 & 289 & & & \\
\hline \multirow{2}{*}{ TP } & Between Groups & 260.482 & 2 & 130.241 & .553 & .576 \\
\cline { 2 - 7 } & Within Groups & 67595.504 & 287 & 235.524 & & \\
\cline { 2 - 7 } & Total & 67855.986 & 289 & & & \\
\hline
\end{tabular}

One-way analysis was conducted to see the difference in teachers' OCB and TP. Table 5 reveals no significant difference concerning teachers' OCB and TP in terms of their academic qualifications.

Table 6: One way ANOVA on OCB and TP regarding teachers' teaching experience

\begin{tabular}{lllllll}
\hline & & Sum of Squares & $d f$ & Mean Square & $\boldsymbol{F}$ & Sig. \\
\hline OCB & Between Groups & 337.237 & 5 & 67.447 & .940 & .456 \\
\cline { 2 - 8 } & Within Groups & 20382.087 & 284 & 71.768 & & \\
\cline { 2 - 8 } & Total & 20719.324 & 289 & & & \\
\hline \multirow{2}{*}{ TP } & Between Groups & 2572.613 & 5 & 514.523 & 2.238 & .051 \\
\cline { 2 - 7 } & Within Groups & 65283.373 & 284 & 229.871 & & \\
\cline { 2 - 8 } & Total & 67855.986 & 289 & & & \\
\hline
\end{tabular}

One-way analysis was conducted to see the difference in teachers' OCB and TP. The table above reveals no significant difference concerning teachers' OCB and TP in terms of their teaching experience.

Table 7: Linear Regression Analysis for effect of OCB on TP

\begin{tabular}{lllll}
\hline Variables & Model $\boldsymbol{R}$ Square & $\boldsymbol{B}$ & $\boldsymbol{t}$ & $\boldsymbol{P}$ \\
\hline OCB and TP & .388 & .623 & 13.512 & .001 \\
\hline
\end{tabular}

Above table 7 indicates that the $R$ square value $(0.388)$ explained the independent variable's variance independent variable. In this case, the variance in OCB is $(.38 .8 \%)$ due to TP. It is interpreted that beta value $(0.623)$ is significant with $p=.001$. It has been concluded that there is a significant effect of OCB on TP at the secondary level with a beta value of 0.623 at $p=.000$.

\section{CONCLUSION AND DISCUSSION}

The primary aim of this study was to explore the relationship between teachers' OCB and TP as teachers produce educator, cognitive, affective, and psychomotor aspects. A teacher performs Organizational Citizenship Behavior (OCB) to the school for positive change except for his job description. OCB is suitable for time management, willingness to become honest in a developing environment. Open-mindedness of teachers' changes, the effort of self-developing, restrain from conflict of coworkers, not complaining attitude, and constant as positive to cover problems. The results revealed that there was a positive and statistically significant correlation between teachers' OCB and TP. Conscientiousness, altruism, citizenship, virtue, generosity, respect are components of OCB that are significant to performance (Khazaei et al., 2011; Troena \& Noermijati, 2013; Sadeghi et al., 2018). 
Regression results reported that teachers' OCB had a significant effect on TP. Teachers who had OCB consequently they were higher performer in the classroom scenario. The study's results are consistent with Abrar and Isyanto (2019), Lestari and Ghaby (2018), (Sari 2015), and Yuwanda and Pratiwi (2020).

In this study, results support the results of previous empirical studies. The results revealed that teachers' OCB is very important and performs an imperative role in blowing their teaching performance and teaching efficacy (Organ, 2018; Somech \& Oplatka, 2015). Teachers' OCB directly influences their teaching performance. The current study recommended that teachers should have OCB to perform their duties in the classroom. OCB may help them to get educational ends effectively.

\section{LIMITATION OF THE STUDY}

The current study examines the association between between teachers' organizational citizenship behavior and teaching performance at the primary level in the Lahore division of Punjab province only, however studies can be conducted by analyzing the association teachers' organizational citizenship behavior and teaching performance at high school level, university level as well. Furthermore, the study could be expended to other provinces of Pakistan as well as could compare Pakistan with other developing and developed economies.

\section{AUTHOR'S CONTRIBUTIONS}

Muhammad Shabbir Ali: Data Analysis and its interpretation, Abstract and Conclusion writing, review of the article after completion, and correspondence with the journal.

Muhammad Siddique: Data Collection, working on Literature, writing references and after completion of research review the article

Ahsaan Siddique: Data Collection, working on Literature and after completion of research, its review.

Muhammad Abbas: Data Collection, working on Literature and after completion of research, its review.

Saba Ali: Data Collection, working on Literature and after completion of research, its review.

\section{REFERENCES}

1. Abrar, U., \& Isyanto, I. (2019). Pengaruh organizational citizenship behaviour (OCB) terhadap kinerja karyawan (Studi pada PT. Urchindize Cabang Madura). JurnalPerilaku dan Strategi Bisnis, 7(2), 106-115. https://doi.org/10.26486/jpsb.v7i2.868

2. ALHussain, A. Z. (2011). Barriers to knowledge management in Saudi Arabia. The George Washington University.

3. Alkahtani, A. (2015). Organizational citizenship behavior (OCB) and rewards. International Business Research, 8(4), 210. https://doi.org/10.5539/ibr.v8n4p210

4. Amin, M., Shah, R., Ayaz, M., \& Atta, M. A. (2013). Teacher's job performance at secondary level in Khyber Pakhtunkhwa, Pakistan. Gomal University Journal of Research, 29(2), 32-38.

5. Askafi, E., Chandrarin, G., Assih, P., \& Respati, H. (2017). Organizational citizenship behavior as a way to improve performance: Evidence from Muslim Teachers in Indonesia. European Journal of Business and Management, 9(27), 36-44.

6. Belogolovsky, E., \& Somech, A. (2010). Teachers' organizational citizenship behavior: examining the boundary between in-role behavior and extra-role behavior from teachers, principals, and parents. Teacher \& Teacher Education, 26, 914-923. https://doi.org/10.1016/j.tate.2009.10.032

7. Darsana, M. (2013). The influence of personality and organizational culture on employee performance through organizational citizenship behavior. The International Journal Of Management, 2(4), 35-42.

8. Deery, S., Rayton, B., Walsh, J., \& Kinnie, N. (2017). The costs of exhibiting organizational citizenship behavior. Human Resource Management, 56(6), 1039-1049. https://doi.org/10.1002/hrm.21815

9. De Geus, C.J.C., \& Ingrams, A., Tummers, L., \& Pandey, S.K. (2020). Organizational citizenship behavior in the public sector: A systematic literature review and future research agenda. Public Administration Review, 80(2), 259-270. https://doi.org/10.1111/puar.13141

10. Dinka, D. D. (2018). Organizational citizenship behavior and employees' performance assessment: the case of Dire Dawa University. American Journal of Theoretical and Applied Business, 4(1), 15. https://doi.org/10.11 648/j.ajtab.20180401.13

11. Fitriastuti, T. (2013). Pengaruh kecerdasan emosional, komitmen organisasional dan (OCB) terhadap kepuasan kerja dan organizational citizenship behavior terhadap kinerja karyawan. Jurnal Dinamika Manajemen, 4(2), 103-114.

12. Ghanizadeh, A., \& Jahedizadeh, S. (2015). Teacher burnout: a review of sources and ramifications. JESUS, 6 , 24-39. https://doi.org/10.9734/BJESBS/2015/15162

13. Grant, A. M. (2017). Solution-focused cognitive-behavioral coaching for sustainable high performance and circumventing stress, fatigue, and burnout. Consultancy Psychology Journal, 69, 98-111. https://doi.org/10.103 $\underline{7 / \mathrm{cpb} 0000086}$ 
14. Hakanen, J. J., Bakker, A. B., \& Schaufeli, W. B. (2006). Burnout and work engagement among teachers. J. Sch. Psychol, 43, 495-513. https://doi.org/10.1016/j.jsp.2005.11.001

15. Hazzi, O.O. (2018). Organizational citizenship behavior: A holistic review. In A. Farazmand, (ed.), Global Encyclopedia of Public Administration, Public Policy, and Governance (pp. 1-12). Springer, Cham. https://doi.org/10.1007/978-3-319-31816-5 3677-1

16. Hemaloshinee, V., \& Nomahaza, M. (2017). Organizational citizenship behavior in the hospitality industry: Bridging challenges, benefits, and contribution. International Journal of Human Capital in Urban Management, 2(3), 243-250.

17. Iqbal, H. K., Aziz, U., \& Tasawar, A. (2012). Impact of organizational justice on organizational citizenship behavior: An empirical evidence from Pakistan. World Applied Sciences Journal, 19(9), 1348-1354.

18. Jafari, P., \& Bidarian, S. (2012). The relationship between organizational justice and organizational citizenship behavior. Procedia- Social and Behavioral Sciences, 47, 1815-1820. https://doi.org/10.1016/j. sbspro.2012.06.905

19. Jex, S, M., \& Britt, T. W. (2008). Organizational psychology a scientist-practitioner approach (2nd Ed.). New Jersey: John Wiley \& Sons.

20. Khan, K. M., Khan, A. M., Ullah M., Usman, A., Farhat, S., (2020). Closing price determination; extent of manipulation and deterrent strategy formulation: a case of Pakistan Stock Exchange. Journal of Critical Reviews, 7(14), 2689-2705.

21. Khazaei, K., Khalkhali, A., \& Eslami, N. (2011). Relationship between organizational citizenship behavior and performance of school teachers in West of Mazandaran Province. World Applied Sciences Journal, 13(2), 324330.

22. Khan, K. M., Ullah M. (2021). Mediating Role of Ethical Leadership Between Employees Empowerment and Competitive Edge: A Case of Commercial Banks in Pakistan. Humanities \& Social Sciences Reviews, 9(2), 219-231. https://doi.org/10.18510/hssr.2021.9223

23. Klotz, A. C., Bolino, M. C., Song, H., \& Stornelli, J. (2018). Examining the nature, causes, and consequences of profiles of organizational citizenship behavior. Journal of Organizational Behavior, 39(5), 629-647. https://doi.org/10.1002/job.2259

24. Konovsky, M. A., \& Organ, D. W. (1996). Dispositional and contextual determinants of organizational citizenship behavior. Journal of Organizational Behavior, 17, 253-266. https://doi.org/10.1002/(SICI)10991379(199605)17:3<253::AID-JOB747>3.0.CO;2-Q

25. Lestari, E. R., \& Ghaby, N. K. F. (2018). Pengaruh organizational citizenship behavior (OCB) terhadap kepuasan kerja dan kinerja karyawan. Jurnal Teknologi dan Manajemen Agroindustry, 7(2), 116-123. https://doi.org/10.21776/ub.industria.2018.007.02.6

26. Makruf , I., Putra, H, R., Muharom., Hafidah., \& Maslamah. (2021). Self-Efficacy, job satisfaction, and organizational citizenship behavior (OCB) for teachers in all state primary schools of sukoharjo: A quantitative analysis. Elementary Education Online, 20(1), 1149-1154. https://doi.org/10.17051/ilkonline.2021.01.111

27. Mamdani, K. F., \& Minhaj, S. (2016). Effects of motivational incentives on employees' performance: A case study of banks of Karachi, Pakistan. Southeast Asia Journal of Contemporary Business, Economics, and Law, 9(2), 32-39.

28. Milk Cabang Yogyakarta. Jurnal Manajemen, 5(2), 61-69.

29. Mokhniuk, A. M. (2016). The impact of monetary rewards on the motivation of employees. Roczniki Ekonomiczne Kujawsko- Pomorskiej Szkoły Wyższej w Bydgoszczy, 9, 336-346.

30. Newstorm, J. W., \& Davis, K. (2002). Organizational citizenship behavior, human behavior at work (11th Ed.). Boston: McGraw-Hill.

31. Organ, D. W. (2018). Organizational citizenship behavior: Recent trends and developments. Annual Review of Organizational Psychology and Organizational Behavior, 80, 1-17. https://doi.org/10.1146/annurev-orgpsych032117-104536

32. Pekaar, K. A., van der Linden, D., Bakker, A. B., \& Born, M. P. (2017). Emotional intelligence and job performance: The role of enactment and focus on others' emotions. Human Performance, 30(2-3), $135-153$. https://doi.org/10.1080/08959285.2017.1332630

33. Podsakoff, N. P., Whiting, S. W., Podsakoff, P. M., \& Blume, B. D. (2009). Individual and organizational- level consequences of organizational citizenship behaviors: A meta-analysis. Journal of Applied Psychology, 94(1), 122. https://doi.org/10.1037/a0013079

34. Sadeghi, G., Ahmadi, M., \& Yazdi, M. T. (2018). The relationship between organizational citizenship behavior and organizational performance (case study: Agricultural Jihad Organization of Mazandaran Province). Business Perspectives, 14(3), 317-324. https://doi.org/10.21511/ppm.14(3-si).2016.03

35. Sari, L. I. (2015). Pengaruh organizational citizenship behavior (OCB), komitmen organisasi dan disiplin kerja terhadap kinerja karyawan pada PT. Ultra Jaya Milk Cabang Yogyakarta. Jurnal Manajemen, 5(2), 61-69. https://doi.org/10.26460/jm.v5i2.192

36. Schaufeli, W. B., \& Buunk, B. P. (2003). Burnout: an overview of 25 years of research and theorizing. In Schabracq, M. J., Winnubst, J. The handbook of work and health psychology (pp. 383-425). West Sussex, England: John Wiley \& Sons. https://doi.org/10.1002/0470013400.ch19 
37. Schermerhorn, John. Hunt, James. Osborn, Richard. and Bien, M. (2010). Organizational Behavior. (L. Johnson, Ed.) (11th Ed.). John Wiley \& Sons, Inc. Retrieved from www.wiley.com/go/returnlabel

38. Shahin, A., Shabani Naftchali, J., \& Khazaei Pool, J. (2014). Developing a model for the influence of perceived organizational climate on organizational citizenship behaviour and organizational performance based on balanced score card. International Journal of Productivity and Performance Management, 63(3), $290-307$. https://doi.org/10.1108/IJPPM-03-2013-0044

39. Shanker, M. (2018). Organizational citizenship behavior in relation to employees' intention to stay in Indian organizations. Business Process Management Journal, 24(3). https://doi.org/10.1108/BPMJ-02-2018-0048

40. Shen, B., McCaughtry, N., Martin, J., Garn, A., Kulik, N., \& Fahlman, M. (2015). The relationship between teacher burnout and student motivation. British Journal of Educational Psychology, 85, 519-532. https://doi.org/10.1111/bjep.12089

41. Shaikh, S., Channar, P., Shaikh, M., \&, Ullah, M., (2021). Financial constraints and listed sugar mills on Pakistan Stock Exchange. International Journal of Management, 12(3), 70-76.

42. Siddique, A. (2016). Relationship between workplace spirituality and organizational citizenship behavior of secondary school teachers at Kasur district (Unpublished M.Phil. thesis). University of the Punjab, Lahore, Pakistan.

43. Silva, H., \& Madhumali, K. (2014). Organizational justice and organizational citizenship behavior: A study of public sector organizations in Western Province. Kelaniya Journal of Human Resource Management, 2(1/2), 114. https://doi.org/10.4038/kjhrm.v9i1-2.9

44. Somech, A., \& Drach-Zahavy, A. (2000). Understanding extra-role behavior in schools: The relationships between job satisfaction, sense of efficacy, and teachers' extra-role behavior. Teacher \& Teacher Education, 16, 649-659. https://doi.org/10.1016/S0742-051X(00)00012-3

45. Somech, A., \& Oplatka, I. (2015). Organizational citizenship behavior in schools: Examining the impact and opportunities within educational systems. Oxford: Routledge. https://doi.org/10.4324/9781315866956

46. Somech, A., \& Oplatka, I. (2014). Organizational citizenship behavior in schools: Examining the impact and opportunities within educational systems. New York, NY: Routledge. https://doi.org/10.4324/9781315866956

47. Somech, A., \& Ron, I. (2007). Promoting organizational citizenship behavior in schools: the impact of individual and organizational characteristics. Educational Administration Quarterly, 43, 38-66. https://doi.org/10.1177/0013161X06291254

48. Troena, E. A., \& Noermijati, N. (2013). Organizational citizenship behavior role in mediating the effect of transformational leadership, job satisfaction on employee performance: Studies in PT Bank Syariah Mandiri Malang East Java. International Journal of Business and Management, 8(17), 1-12. https://doi.org/10.5539 lijbm.v8n17p1

49. Ullah, M., Shaikh, M., Channar, P., \& Shaikh, S., (2021). Financial forecasting: an individual perspective. International Journal of Management, 12(3), 60-69.

50. Ullah, M., Malik., A.M., Zeb, A., Rehman, A. (2019). Mediating Role of Capital Structure between Corporate Governance and Risk. Journal of Managerial Sciences, 13(3), 47-56.

51. Yuwanda, T., \& Pratiwi, N. (2020). Pengaruh organizational citizenship behavior dan kompensasi terhadap kinerja karyawan PT. Semen Padang dan work overload sebagai variabel mediasi. Procuratio: Jurnal Ilmiah Manajemen, 8(1), 53-62. 